Нина Аксиќ

\title{
НАРОДНИТЕ ОБИЧАИ ПРИ РАЃАЊЕТО НА ДЕТЕТО И ВО ТЕКОТ НА ПРВАТА ГОДИНА (ВРЗ ПРИМЕРИ ОД СРПСКАТА ЗАЕДНИЦА ВО НОВИ ПАЗАР $)^{1}$
}

\begin{abstract}
Апстракт: Во текстот ќ бидат претставени и коментирани традиционалните обичаи, кои се однесуваат на стекнувањето одредени способности од страна на детето во неговата прва година од животот, но и обичаите што се поврзани со самото раѓање и крштевање на детето. Посебно внимание ке биде насочено кон обичаите што ги практикуваат членовите на српската заедница во Нови Пазар, а со оглед на тоа дека во ова место Србите се малцинство, од особено значење е претставувањето на начините со кои се овозможува зачувувањето на старите традициски обрасци - како еден од модусите за самоодржување на етницитетот во мнозинската муслиманска средина. Целта на авторот е да го презентира богатството на споменатите обичаи, но и нивната модификација во современиот миг, оние што се создаваат како последица од општите општествени промени или поконкретно од промените што се однесуваат на општеството, на културата и на економијата во Србија.
\end{abstract}

Клучни зборови: народни обичаи, дете, растење, првата година од животот, Нови Пазар.

Во народната традиција, обичаите во врска со детето можат да се следат почнувајќи од оние што се однесуваат на бебето додека е во утробата на мајката, т.е. бремените жени, преку оние обичаи поврзани со растот на детето, до обичајната и ритуалната практика, земени во најширока смисла (обичаи од календарските и од животните циклуси).

Во овој труд ќе зборуваме за обичаите што се однесуваат на раѓањето и на растењето на детето до неговата прва година. За да можеме да го презентираме прегледот на овие обичаи на територијата на Нови Пазар, т.е. на Новопазарската област, мораме, пред сѐ, кога зборуваме за периодот до осумдесеттите години, да имаме предвид дека овие обичаи во најголем број случаи биле поврзани за селските семејства, коишто токму во овој период во голем број се селат во градот и на тој начин започнува трансформацијата на обичаите. Всушност, треба да се има предвид дека во Србија, поради миграцијата село - град, „процентот на селското население паднал под половината на населението (Ристовић и Стојановић, 2001, 11)“. Беше посочено дека ќе се зборува за обичаите што се однесуваат на српското население во оваа област, бидејќи во неа живеат главно Бошњаци, па во врска

\footnotetext{
1 Трудот е настанат во рамките на проектот Стратегије идентитета: савремена култура и религиозност (177028), кој во целост е финансиран од страна на Министерството за образование, наука и технолошки развој на Република Србија (Министарство просвете, науке и технолошког развоја Републике Србије).
} 
со ова, традиционалната обичајна практика има посебно значење во зачувувањето на идентитетот на Србите на овој терен. Селектираните искази од етнолошките транскрипти во овој труд ќе бидат претставени како илустративен материјал, кој е направен врз основа на аудиозаписите што настанале во 2016 и во 2019 година. Покрај од соговорниците, ${ }^{2}$ авторот дошол до податоци, што се однесуваат на темава, со помош на присуство на некои од овие обичаи и обреди, како набљудувач, од една страна, но и како учесник во нив, од друга (на пр. за бабини/повојница, крштенка, прво запче и др.).

До 80-тите години на 20 век, во селата на новопазарскиот крај живееле многубројни семејства со пет или со повеќе членови (дури и со повеќе од десет членови), а многу жители на селата живееле во задруги со блиски роднини и со нивните семејства. Овој начин на живеење со себе донесол и одредени правила, обврски и поредок, кои морало да се почитуваат за да можат да функционираат на најдобар начин. Патријархалниот систем бил, а може да се забележи, и останал во овој регион - основен начин за разбирање на семејните односи и вредности, додека „патријархалното семејство (е) било чувар на традицијата, на обичаите, на воспитанието, кои се пренесувани од возрасните на децата. Семејството било и 'последната заштита' од 'опасноста на надворешниот свет', кои на разни начини сѐ повеќе и сѐ подлабоко пробивале во тој некогаш неприкосновен простор (Ристовић и Стојановић, 2001, 19)“. Така, жените и децата имале посебни обврски, независно од мажите, но и одредени забрани на кои морало да им се покоруваат.

Обичаите што се однесуваат на детето започнуваат од неговото зачнување и траат во текот на целата бременост на мајката. Некогаш за бремената жена се наметнуваат различни забрани со кои се оневозможува појава на некаков проблем, белег или нешто слично или „оние дејства штоасоцираат на тешко или ненормално породување (Требјешанин, 1991, $68)^{“}$. На пример, на бремените жени им се забранувало „да крадат“ цреши од дворот на соседот, зашто се сметало дека кога ќе се роди бебето, тоа ќе има некаков белег на кожата во форма на цреша. Бремените жени во селата околу Нови Пазар генерално биле рамноправни со другите жени и со мажите при работата. За бременоста не се водело сметка премногу, зашто морало да се работи и да се заработи за живот. Бремените жени переле, ја чувале стоката, ги молзеле кравите, работеле и на нива и ги извршувале сите други домашни работи до самото породување.

\footnotetext{
2 Посебна благодарност за издвоеното време, како и за драгоцените податоци им должиме на соговорниците од Нови Пазар - на Весна Аксиќ (1966, род. Војковиќ Нови Пазар, омажена во Леча - Нови Пазар), на Слободан Аксиќ (1961, Леча - Нови Пазар) и на Влада Макојевиќ (1947, род. Тревиќ - Лешак, мажена за Цоковиќ - Нови Пазар). Нашите соговорници, во наведените транскрипти со сегменти од разговорите, се претставени со скратениците В, С и ВЛ, додека испитувачот е претставен со скратеницата И. Графичкиот знак „, (...) “ што се користи во транскрипцијата на аудиозаписот служи со него да се означи изоставен дел од текстот поради неразбирливиот говор или кога некој дел од текстот нема потреба да се претстави во дадениот момент.
} 
На денот на породувањето, кога родилките ќе ги почувствуваат првите родилни болки, тие се повлекуваат во друга постара куќа или соба, во некој додатен објект, најчесто во штала, т.е. на некое место, каде што на подот има земја или бетон за да може просторијата полесно да се измие и за да се спречи, остатоците од породувањето, да ги види мажот. При породувањето на родилките им помагале поискусни жени од селото, најчесто оние што се најблиску до родилката, како што се јатрвата (сопругата на деверот) или свекрвата (мајката на сопругот): Само неку, неку жену углавном да има ту, старија млађа нема везе, главно да је поред юе (ВЛ). Некои жени, кои почнувале да се породуваат на нива или додека го чувале добитокот, се криеле под некое дрво и самите се породувале, при што ја сечеле папочната врвка со нешто остро - со брич или со камен. Значи, жените морале да бидат исклучително снаодливи во вакви моменти, за што сведочи и исказот на една од информаторките, која, со својата јатрва и со сопругот, тргнала во болница низ шумата, но се породила во шумата: Ја сложила била пелене, све. Ајде пелене, флашу воде. Ау нисмо понели ништа оштро да пресечемо пупак. И ми потрчимо, ја идем на ниже, идемо отишли смо ја мислим једно више од два километра од куће. (...) Ја чучнем на колена и дијете пану. Врисну онако. На шодер, ту му било мало почрвенело. И она фркну шибииу, вели сина си родила, ал немамо чим да пресечемо пупак. Куку како ћемо. Она ил узела неки каменчић ил је овако урадила (показујући као да је рукама прекинула пупчану врпиу) и сад нисам је видела (ВЛ). Важно било да се има малку вода за да има со што да се измие детето веднаш: И она је само рекла мене, држи флашу, cunaj. Да га окале оно старе жене ладном водом. То тако било (ВЛ). По породувањето жената прво морала сама да се врати дома ако се породила надвор, а потоа и да ја исфрли постелката притискајќи го стомакот. Закопувањето на постелката кај нашиот народ била честа појава, а тоа се сметало за добро решение, зашто, во спротивно, можела да падне во канџите на вештерката. ${ }^{3}$ И ба.., тамо у шуму, само зачепрљам (ВЛ). Во посебна просторија, најчесто покрај шпоретот и на слама со едно ќебе, родилката ги поминувала првите неколку денови, додека „не се исчисти“. Тука ѝ била носена храна, а на таа слама за првпат го повивала бебето. Така, „нечистата“ родилка не смеела да ги мие садовите, ниту да работи што и да било околу куќата и добитокот, во првите две седмици. ${ }^{4}$ То је, то је некад било. То сад нема. То је некад било, породиља око десет, петнајст дана тамо спава у другој соби, нити народ долази да је обиђе, нити... Разумеш то као, као казали су прљава, е (В). Три, три дана највише, после су морале одма нешто да раде, то није било као сад. Три дана највише би одморила и... Није могла да дира судове и то нису дали стари, док не дође водича (ВЛ). Се забележува дека во ниту еден од двата претставени исказа не се спомнуваат нечистите сили што владеат во текот на првите денови, туку дека обичајот за

\footnotetext{
${ }^{3}$ Повеќе за обичаите поврзани за постелката да се види во: Требјешанин, 1991.

${ }^{4}$ По породувањето, родилката не можела да „биде видена по неколку дена, повеќе заради обичај отколку заради одмор, а потоа повторно почнувала да ги извршува сите работи, како и обично“ (Ђорђевић, 1941, 81).
} 
одвојувањето на родилката се поврзува со чувството за вистинска нечистотија и за некаков вид срам - да се излезе пред светот, особено пред машкиот, во „таква состојба“.

Децата претставуваат голема среќа во семејството, „не само за родителите, туку и за роднините и за општеството. Штом ќе дојде на свет детето, веднаш се објавува тоа на сите страни (Ђорђевић, 1941, 87)“. Во новопазарскиот крај не бил редок случајот да се пука кога ќе се роди дете, особено машко.

Нашиот народ смета дека родилката и бебето, веднаш по породувањето, ce „нечисти“ и дека ним можат да им се приближат различни нечисти сили. Од оваа причина се смета дека - тие се 'опасни' за својата околина (Требјешанин, 1991, 117), па затоа нивното „магиско чистење се врши со низа обреди, кои започнуваат веднаш по раѓањето и траат сѐ до четириесеттиот ден“ (Требјешанин, 1991, 117). Еден од првите обичаи што се однесува на бебето е одењето „на водичка“ и добивањето име „на водичка“. Некој од домашните (на пример, постарата сестра или постариот брат), по раѓањето на детето, одел во црква кај свештеникот по света водичка, и тогаш тој им давал име за детето: Он ту водицу очита поп и каже тако и тако име. Они имају тамо именик. И он, и ко оде да узме то понесе неку, понесе неку флашу и онда, и он после рекне ја би такво име, а ви можете да мењате (ВЛ). Мајката, ако сака - го задржувала тоа име, но можела и да го промени. По водичка се одело веднаш штом ќе се породи жената, а потоа таа со оваа водичка малку се замивала себеси, но и бебето. По ова, она водииу може да распе после само на чисто место. Ако ће неки пут да се умије или да знаш довати груди, због млека и после проспе Ђе чисто. Ђе се не гази (ВЛ).

Покрај ова, чест бил и обичајот да се избере име за детето според празникот на кој се родило тоа, а се сметало и дека детето што е родено на одреден празник може да има некои посебни способности или нешто слично на тоа. Така, на пример, се смета дека ако детето се роди на Голема Богородица (28 август), тоа ќе биде голем господин во својот живот. Она што е важно е тоа што името многу често претставува и „магиски вид на заштита на новороденчето од зли сили што му го загрозуваат животот“ (Требјешанин, 1991, 136). Исто така, се сметало и тоа дека светецот, на чиј датум се родило детето, ќе му помогне нему во животот. Во врска со претходното е и теренскиот исказ, кој се однесува на раѓањето на болно дете на празник: Викао неки човек, имао ћерку, даље га било од ове куће, глувонему. (...) И он викао, вели, ово ми се дијете само, можда вели увече празника створило. И то треба да гледамо (ВЛ).

На првото ритуално капење, во некои делови од Србија, во водата се става сребрена паричка, некаква тревка и сл. Во Нови Пазар не е познат ваков обичај. Единствено нешто што било важно е: водата, во која првпат се капе детето, да се истури на некое чисто место, каде што не се гази. Најверојатно е дека овој обичај е поврзан со напредокот на детето, како и со тоа детето ритуално да не се „извалка“, т.е. да не го обземат нечистите сили.

Доењето било исклучително важно за создавање врска меѓу мајката и бебето, заради здравјето, но и како „мистично, спасоносно средство за 
одржување, напредок и секаква среќа“ (Требјешанин, 1991, 179). Се сметало дека детето треба да се дои една или две години. Сепак, имало и такви случаи кога детето се доело и до петтата година. Како што се дознава на теренот, доколку мајката немала млеко за бебето, не било ретко, во селото, да се пронајде некоја жена која има малку постаро дете, но која, сѐ уште, има млеко, па родилката да го носи своето новородено бебе на подој кај таа жена. Родилките најчесто пристапувале кон ваквиот начин на доење, затоа што во тоа време немало како денеска други начини за прихранување на бебињата. Покрај оваа помош од друга доилка, тогашните доилки имале на располагање уште и млеко од животинско потекло.

Бидејќ се сметало дека бебето и родилката се нечисти во првите четириесет дена од породувањето, тие не смееле да излегуваат од куќата. Сепак, оваа забрана во поголемиот број случаи не можела да се почитува затоа што мајката морала да се врати на работа по нивите и околу добитокот, само неколку денови од породувањето. Затоа, кога жената „ке се исчисти“, се мисли на оние неколку први денови по породувањто, таа им се враќа на сите обврски што ги имала дотогаш во куќата, при што ја преземала и грижата околу бебето. Бебето морала да го капе, да го повива, да го дои или да го храни, да го положува во колепката, а потоа да оди на нива, да се занимава со добитокот, да ја суредува куќата и да пере. Во врска со ова „постојат податоци дека тогаш кога немало кому да му ги остават децата на чување, мајките, на поле, носеле и сосема мали бебиња, кои, во неповолни услови, поминувале по цели денови на отворено“ (Ристовић и Стојановић, 2001, 10). Како што дознаваме од информаторите, често се случувало мајките да ги оставаат штотуку родените бебиња сами во куќата, додека не ги измолзат кравите или додека не ги исперат алиштата во потокот, откога ќе ги искапат, ќе ги нахранат, и добро ќе ги замотаат во колепката, по што бебињата ќе заспијат: $A$ знаш ита смо радили? Ми смо повијали колевку. (...) То је направљено ко коританце. Отуд и отуд оне њене за повој. (...) И кад би плеле повој од вуне оволико широко исплеле би, ја сам плела, горе све после с краја уже да би повијала (???). Беба је доле у колијевци у пелену. И ми отуд и отуд само, не би око ње знаш. После мало једном око ногу и тамо закачимо и завриимо. Е то и после тамо уже с краја завршила (ВЛ). (...) А јел сте бебу скроз повијали (И)? (...) Нисмо имали памперс, ништа, него смо имали пелене. Моја мајка, на пример, ја сам купила пелене, то метар са метар оно, и ставим ово, неколико отуд поврнем, ставим у колијевку. Колијевка ту стављено ко јастуче неко доле. Па после другу пелену, па једну око главице, како му савијем туда онако оно, другу јену мало по вру, отуд и отуд и повој да ухвати. И доле завијем ногиие (ВЛ).

Пелените, па и долната облека, главно, се сушеле надвор, освен зимно време кога алиштата ги ставале да висат над шпоретот. Она за што исклучително воделе сметка е тоа дека ни пелените ни долната облека не ги оставале да преноќат надвор, зашто се сметало, особено во првите „четириесет дена од раѓањето на новороденчето дека тоа е 'нечисто“ и подложно на влијанијата на демоните од долниот свет. Затоа во овој период бебето посебно се чува да не падне под нивно владение и влијание. Облеката, која му 
припаѓа на бебето, не смее да остане надвор преку ноќ, зашто хтонските демони тогаш се собираат околу куќата“ (Кулишић, Петровић и Пантелић, 1998, дете). Така и нашите испитаници ја потврдуваат оваа забрана со навестување дека тоа не смее да се прави, но не објаснуваат прецизно зошто: А то смо купили напољу. А кад је нешто, те баш киша ел нешто, нема де ниђе испод стреје да се обеси, ми смо морали око шпорета да их сушимо, око фуруне, није био шпорет (ВЛ). (...) А значи ноћу, кад крене мрак да пада, то не сме (И)? Мицали смо, ваља се због деце, кад расту. Мицали смо ми и веш, и све оно, да (ВЛ).

Значи, важно било да се чуваат родилката и бебето од породилните демони, кои се нарекуваат бабици: „Бабиците (...), всушност, се душите на умрените предци, кои доаѓаат, по раѓањето на новородениот член на родот, да му ја одредат судбината“ (Кулишић, Петровић и Пантелић, 1998, бабище). Покрај бабиците, судбината на новореденото дете ја определуваат и т.н. наречници. Некаде бабиците и наречниците се поистоветуваат, додека на други места се смета дека наречниците се појавуваат само еден ден, а бабиците во текот на четириесетте дена по породувањето и „сакаат да ги изморат и детето и родилката, а се мисли дека тие најмногу дејствуваат ноќе, и тоа истовремено повеќе од нив“ (Кулишић, Петровић и Пантелић, 1998, бабице). Како заштита од бабиците, но и од уроците, воопшто, - што може да ги направи кој и да било од нив, ако ги погледне бебето или родилката со зли или со урокливи очи - се сметало дека е најдобро во близина на родилката или на бебето да се стави лук или некаков црвен предмет: „Така, на детето и на родилката, или покрај нив, секогаш се наоѓаат лук и црвен конец, односно црвена волна“ (Кулишић, Петровић и Пантелић, 1998, бабице). И во новопазарските села, како заштита од уроци, обично, околу колепката на детето се врзувале лук и некаква црвена волна: И на повој би нешто пришивале старије жене, као нешто, као нешто ирвено или неки брошић или, или бијели лук у нешто уплете, па ту пришије као беби да не оде на очи. (...) Тако старије жене, а ми... (ВЛ). Доколку се случи детето да биде урочено, постоеле и посебни начини за да се тргнат уроците. Во Нови Пазар имало, а и денес има жени, главно, од муслиманска вероисповед (Бошњачките или Ромките), кои се занимаваат со т.н. „леење на стравот“, т.е. со елиминирање на стравот. Ако се забележи дека детето често прета, се сепнува, претерано плаче и друго, го водат да му се излее стравот, така што над главата му се гаси јагленче и онаа форма што ќе му се излее претставува она од што се плашело детето дотогаш. Откога ќе се излее стравот, тој страв засекогаш исчезнува и детето повторно може да живее и да се однесува нормално. Така, според кажувањата на информаторите, детето и на шест години мокри во кревет и сонува големи топки, кои паѓаат врз него, сѐ додека не го однесат да го излее стравот. Над главата му се излева човек, што е поврзано со стравот на неговата мајка, која се исплашила од пијаница на која налетела во мракот додека била бремена. По ова, детето веќе немало проблеми. Значи, за да не дојде до вакви проблеми, се сметало дека за време на првите четириесет денови, мајката не смеела да излегува од куќа, ниту, пак, да го изнесува детето надвор, за, случајно, да не го изгуби млекото, а и за да не го урочи детето 
некој. Со оглед на тоа што мајката морала да ги извршува сите работи во куќата многу бргу по породувањето, од кои некои се и надвор од куќата, таа морала да излегува надвор, но се трудела да не ја видат голем број луѓе.

Бабините во новопазарскиот крај го претставуваат моментот кога роднините и комшиите првпат доаѓаат да ги посетат родилката и бебето. Ова обично се случувало во текот на првите четириесет дена, до крштенката, зашто смислата на овој обичај е „непрестајно чување и бдеење над родилката и над детето“ (Требјешанин, 1991, 125). Но, во некои села на новопазарскиот крај, на бабини се одело дури по четириесет дена од раѓањето на бебето, токму од причина што во текот на првите четириесет дена мајката и бебето морало да бидат чувани од демони и од уроци. Оваа разлика во терминот за извршување на обичаите, може да се доведе во врска со честото мешање на бабините со обичајот наречен повојница што се одвива „по три, по седум или по четириесет дена“" (Требјешанин, 1991, 125) кога, на детето, му се даруваат појас, покривка, пелени и колепка. Разликата меѓу овие два обичаја е во нивната функција. Имено, со повојницата на бебето му се обезбедува добра мажачка/женачка. Сепак, во новопазарскиот крај, како повојница се именува исклучиво вид на подарок, т.е. повој што го носи мајката на родилката или, пак, родилката сама го плете од бела волна. Повојницата се носи на бабини со другите подароци што му одговараат на овој обичај и на неговата функција, додека, пак, на некои места доаѓ до измена на терминот за извршување на обичаите (пред и по четириесет дена), што може да се доведе во врска со мешањето на овие два обичаја (бабини и повојница). На бабини прво доаѓала мајката на родилката и најтесното семејство, а потоа комшиите и останатите роднини и пријатели. Главно, се водело сметка првите гости да бидат само жени. Како понада на мајката и на бебето им се носела облека за бебето, и тоа: штиркани чорапчиња, џемперчиња итн. Од храна, единствено задолжителна била погачата што ја носела мајката на родилката, како и шише со ракија: Је л има назив та нека погача (И)? Па као ваља се кад је рођено дете. (...) И то се ваља за напредак (ВЛ). Бидејќи српските семејства во селата на новопазарскиот крај, главно не биле имотни, најчесто како подароци се носеле горенаведените, што може да се види и од следниов исказ: А нешто од злата, накит (И)? Није се имало Бога ми, па није имало злата. Моји мене нису доносили злато (ВЛ).

На четириесеттиот ден, детето се изнесувало надвор и најчесто требало да се одведе на три места, кај некои најблиски комшии или роднини. $E$ кад напуни четрдесет дана, тог дана треба негде да га изведеш. Небитно, код комшинице прве, код својте неке ко ти је близу ту, разумеш. Али тог дана да се изведе негде (В). И ита они дају том детету (И)? Обично дају два јаја. То је обичај (В). Се смета дека јајце му се давало на бебето како еден вид желба тоа да биде бело како јајце.

По четириесеттиот ден, т.е. по нечистиот период, поради многу болести, кои некогаш биле смртоносни, ${ }^{5}$ роднините на детето се стремеле тоа да се

5 „Семејствата на село имале доста деца, но поради лошите услови за живот и болестите, нивната смртност била голема. На пример, во Кралството Југославија 
крсти колку што е можно побргу, ${ }^{6}$ иако во новопазарскиот крај во минатото имало примери и со крштевање дури по една година. Крштевањето, како важен сегмент на традиционалната култура кај народите со христијанска религија, и како дел од животниот циклус, се смета за начин на: одбрана од нечистите сили, заштита, а потоа и како влез во Царството Божје. На овај начин се „одржува и важната врска со другите семејства (кумството)“ (Ристовић и Стојановић, 2001, 20). Кумот, духовниот татко, како најважна фигура кога станува збор за крштевањето, таткото на детето го поканува со т.н. „буклија“ (украсено шише со ракија). Во други новопазарски села, пак, се сметало дека на детето треба да му се избере кума и тоа кумата да биде девојка, која еден ден ќе се омажи и ќе замине од селото, со што ќе се избегне евентуална кавга меѓу кумовите. А како се кум бира (И)? Па знало се. Моја..., или очева сестра, на пример. Она је била двојка код нас и она је волела да, држала братскија двоје и волела да држи троо. И држала мојега Миланка. А после ова другу од девера ћерка и треће, ова Милинко ми друга исто од девера ћерека држала. (...) Све девојке. Је вели не ваља се да држу мушки. Не, сутра неких, као бојаги, пу, нечег, се не закаче кад неки оде у село, па може и да куне, а ове се удају и онда... (ВЛ). Кумот има право и обврска да му даде име на детето. Некогаш кумот го имал целосното право да избере какво сака име за детето, без да се договари со родителите, а понекогаш дури ни родителите не смееле ништо да му предложат на кумот. Сепак, имало и такви мајки, кои самите сакале да им дадат имиња на своите деца, па се договарале со кумот. Во новопазарскиот крај самиот чин на крштевање се одигрувал во претпладневните часови, зашто се сметало дека со „напредувањето“ на денот ќе напредува и детето во својот живот. По крштевањето, кумот требало да му купи на детето некаква кошула, најчесто бела, додека родителите имале обврска да го даруваат кумот.

Ритуалното стрижење, кое се правело во првата година од животот на детето или откога детето ќе наполни една година, се извршувало дома, а главниот актер бил кумот, како што се истакнува во новопазарскиот крај, венчаниот кум на родителите или некоја тетка. Кумот можел да го истрижи детето само малку, само едно перче коса, или, пак, сосема. Функцијата на овој обичај е „на детето, на магиски начин, да му се осигураат: здравјето, благосостојбата, поволниот развој и плодноста“" (Требјешанин, 1991, 196). Во новопазарскиот крај се смета дека не е добро за детето тоа да се стрижи пред крштевањето, па овој обичај се изведувал по крштевањето, а тоа можело да се случи дури и откога детето ќе наполни една година.

Додека детето не наполни една година, се сметало дека нему треба да му пораснат неколку запчиња. Така, оној што прв ќе го види запчето на детето требало да се дарува со нешто бело. Знам кад зуб први изникне, за зуб, ко први види, купи му нешто бело. Или белу марамищу, или белу мајиу, или боди бели и

наталитетот уште од 1927 до 1933 година се движел меѓу 34,2 и 31,14 0/00, додека умирале 14,4 0/00“ (Ристовић и Стојановић, 2001, 20).

${ }^{6}$ Во некои краеви на Србија, крштевањето се извршувало веќе по три, седум или десет дена од раѓањето на бебето/детето. 
небитно шта је, али бело да буде (В). Покрај дарувањето, постои и мислење во новопазарскиот крај дека детето на кое доцна му изникнал првиот заб, - ќе биде тврдоглаво.

Уште еден интересен момент бил дупењето на ушите на девојчињата уште во првите неколку месеци од животот и со ставање, главно, на златни обетки, што се сметало за добра и пожелна работа т.е. „себап“. Од литературата се дознава дека обетката е една од најчестите метални амајлии, а дека златната обетка најмногу се избира „поради тоа што златото има магиско-заштитна моќ, како и поради тоа што се смета дека златото 'ги одбива уроците и секаков вид пакост““ (Требјешанин, 1991, 147).

Кога станува збор, пак, за одбивањето од цицање, кое најчесто се случува кога детето веќе има една година, најважно било да не се враќа детето на дојка, за да не стане тоа злоочно, т.е. урокливо. Прекинувањето на доењето најчесто се вршело така што мајката ѝ го оставала детето на свекрвата на една ноќ и заминувала да спие во друга просторија.

Во новопазарскиот крај постоеле уште неколку забрани што се поврзани со детето до првата година од неговиот живот. Тоа се, на пример: забраната на детето да му се сечат ноктите, со следново образложение: A шта има мало $и$ да му сече. Има неко сече, неко јок (ВЛ). Неко сече, неко не, ал то се раније није секло (В). То се само скида (ВЛ). Је само опадало (В). Знаш оно би рекли јао неки му попадају (ВЛ).; потоа забраната да се гледа детето додека спие: Знам да се причало да не ваља. Као нешто не ваља да се дете гледа док спава (В).; забраната да се огледува дете во огледало: $E$ то не би дали. Е не знам што, а углавном не би дали (ВЛ). (...) То се ја сећам кад ка... Знаш зашто је то Владо? Док дете не проговори (В),; како и веќе спомнатата забрана детето да се стриже до крштевањето.

Одбележувањето на првиот роденден не било посебно застапено, пред cѐ, поради недоволно финансиски средства, но на детето, сепак, му се купувало или му се плетел подарок, кој, главно, бил нешто за облекување.

Кон крајот на осумдесеттите години од 20 век, со селењето на сѐ поголем број луѓе од село во град, со демократизацијата на културата, а под влијание на социјализмот со постепеното потиснување на традицијата, овие обичаи донекаде се менуваат т.е. се губат некои стари, а се формираат нови или се преобразуваат некогашните и се приспособуваат кон новото време и кон новите општествени услови во градот. Но, поголемиот број обичаи се зачувани и како такви претставуваат сегмент од српската традиционална култура, па и од српскиот идентитет, кој е исклучително значаен за опстанокот на Србите во новопазарскиот крај, каде што населението е претежно со муслиманска вероисповед, па со самото тоа, донекаде има и други обичаи. До промената на определни обичајни практики доаѓa и со многубројни, исклучително големи промени, кои ги доживува целото семејство, т.е. со промените во семејните односи. Значи, овие промени најмногу се случувале поради: миграцијата село - град, што придонесло кон 
тоа значително да се смали бројот на селското население; потоа „постепено (се) распаѓаат овие големи сложени семејства (задруги), во кои во една заедница живееле неколку генерации“ (Ристовић и Станојевић, 2001, 21), па оттука патријархалното семејство се соочувало со предизвиците на модерното општество и со новите политички уредувања, кон што придонесува и поголемата самостојност на жената, која станува сѐ помалку зависна од мажот и од семејството и др.

Со сето што беше наведено претходно, но и со малку подобро образование, жените го сфаќаат значењето на лекарите, поголемиот број жени се породуваат во болница (дури и оние жени од селата), па, сепак и во осумдесеттите години на минатиот век, се случувало некоја жена да остане во селото да се породи. Така, со модернизацијата, како и со менувањето на релацијата маж - жена, но и со еманципацијата на жената во општеството, со текот на времето се исфрлил и обичајот, според кој жената не смее да излезе од една просторија во првите неколку денови по породувањето, па дури и по една недела. Особено ова се однесува за летниот период кога родилката со бебето излегува надвор од куќата. Овде ќе наведеме еден илустративен коментар за односот кон еден стар обичај што се однесува на забраната за излегување на родилката од една просторија, виден од денешна перспектива: Храну само јој тамо, Боже стварно које су то глупости биле. Нина немој да ме питаш то, то је глупо. Па немој да ме питаш. Куку стварно које су то, мајко моја (B).

Еден обичај што е од понов датум е обичајот за собирање гости во куќата на таткото на штотуку роденото бебе или во некој ресторан (кафеана), првата или втората вечер по раѓањето на детето, додека мајката со бебето е во болница. Таткото е главен организатор на ова собирање, на кое се пие и „се мези“, се весели и му се кине кошулата на новопечениот татко: Одма оно вече долазе. Чим чују да се родило дете одма овај (В). Позовеш редом (С). Позовеш најужу родбину и онда ту се спреми трпеза. Пију, пију до ујутру (B).

Во Нови Пазар, сепак, се има одржано обичајот на одење на бабини и тоа на, речиси, идентичен начин, само што ова е подигнато на „повисоко ниво“, со собирање на сите роднини во ресторан, при што подароците, главно, се исти: То обавезно после најужа родбина донесе на пример, ко је близак, донесе торту, мени је нада торту донела, доносила, тад су биле пелене, паковање пелена. Стрии паре, стави на (...?), да детету. (...) И погача, да, да и погачу исто. (...) То обично погачу и то донесе на пример ко има свекрву разумеш и то. Свекрва обично донесе млади погачу. И мени Веца донела, ја, Веца ми је донела погачу, кајмак, не знам ти шта, не знам ти шта. Кад је дошла први пут, оно баш оно по старински оно. Е сад нешто праве оно знаш, по кафанама и то (В). Таканаречените понадици, што им се носеле на мајката и на новороденчето, биле задолжителни. Кој и да дојде на бабини има „обврска“ да донесе некаков подарок во смисла на понадица, т.е. бисквити, сок, овошје и др. Понуде обавезно, плус. (...) Плус овај за деиу ти донесу (C). (...) Обавезно. Понуде, сок, банане, нешто воће (В). (...) А кум кад дође у nосету, шта он доноси (И)? Паре, само паре (С). 
Обичаите што се однесуваат на бремената жена и на родилката, сѐ повеќе се губат, додека обичајот родилката да не излегува од куќата во првите четириесет дена останал, за да не се случи некој да ги урочи неа или бебето: $E$ а четрдесет дана је то по стра, старински овде код нас да се дете не води нигде. Док не напуни четрдесет дана да се дете не изводи, не иде нигде (В).

Обичаите, т.е. дејствијата што се однесуваат на уроците и денес се исклучително изразени. Така и ден-денес се лее страв, но поради непостоењето на колепка и ставањето на нешто црвено или на лук во неа, на децата им се врзува конец околу раката, што е, како што истакнуваат соговорниците - од понов датум.

Обичајот на дупење уши на женските бебиња е останат, па дури и денес е застапен и во градската средина. Исто така, и обичајот да се дарува детето со нешто бело, кога ќе се здогледа првиот заб, и понатаму опстојува. Останатите спомнати табуа, како што се забраната за сечење нокти во текот на првата година, стрижењето пред крштенката и др., најчесто се губат.

Самиот чин на крштевање е останат во домените на православната верска традиција на Србите и се нема променето, освен што за кум се избира кој и да е (поблизок роднина, женско или машко, другар или другарка на родителите и сл.), по избор на родителите. Понекаде, сепак, и по деведесеттите важело старото кумство. На пример, често се случува за кум на децата и натаму да се зема венчаниот кум или синот на старосватот. Покрај промената при изборот на кумот, не се брза ни со крштевањето, најверојатно од практични причини, но и поради тоа што смртноста на новороденчињата значително е смалена со породувањата во болниците. Она што често се прави, дури кога детето ќе наполни една година, е крштенката и првиот роденден да се прослават во ист ден, значи на првиот роденден на детето, на начин што личи на свадба.

Прославата на првиот роденден претставува сосема нов обичај, што е, можеби, резултат од глобализацијата, но и на сѐ поголемата мегаломанија на денешново време. Мошне често се случува крштенката да се прави дури со навршена една година на детето, најчесто поради овие практични причини, така што прославата на крштенката и на првиот роденден се прават заедно. Првиот роденден, главно, се прославува во ресторан или во игротека, со музика, гости, торта и останати придружни елементи. Со ваквата голема прослава завршува еден важен период во развојот на детето и во стекнувањето на првите вештини.

Од претходно изнесените факти од теренот може се забележи дека многу обичаи се табуизирани во смисла на „чини“ или „не чини“, без јасно значење зошто нешто е добро или не е добро да се направи. Втор интересен случај е прагматичниот одговор на информаторите, кој доаѓа како резултат од непознавањето на определен обичај, т.е. непознавањето на неговото значење, па така, на прашањето дали детето смее или не смее да се огледува до првата година од животот и зошто, може да се сретне следниов одговор: Wma ће 
макању да огледнују Бога ти (ВЛ)?, или одговор на прашањето зошто е забрането да се гледа детето додека спие: Шта има да га гледам, ја једва чекам да одем да донесем воде (ВЛ). Но, да донесем воде, у праву си. Ил да оперем пелене, а не да га гледам (В). Прагматичните одговори сосема се во согласност со тешкотиите во животот т.е. со условите за живот во оваа рурална средина, во која немало многу можности, но ни потреба за размислување за вакви работи, освен стремеж да се опстане, да се преживее, да се прехрани.

По увидот во насобраната и тука само делумно претставена граѓа, која се однесува на обичаите поврзани за првата година од животот на детето, јасно е дека обичајната практика била, но и останала, исклучително богата и сложена. Секако мораат, пред сѐ, да се земат предвид специфичните историски процеси и настани во текот на втората половина од 20 век, но и од почетокот на 21 век, со цел согледување на етнолошките промени, т.е. на трансформацијата на одделни обичаи, како и на формирањето некои нови. Тука, само донекаде и тоа исклучиво во еден мал сегмент на народната традиција, може да се следи културниот (дис)континуитет меѓу традиционалниот и модерниот културен концепт. Сепак, покрај тоа што се забележуваат извесни промени, остануваат и натаму основните црти на одредени обичаи. Важно е да се истакне дека во овој крај и денес опстојува патријархалниот модел, дури во некои зафрлени села, речиси, со своите примарни карактеристики, додека во градската средина е во голема мера полиберален, така што е можно, поради оваа причина, некои обичаи уште да наоѓаат своја примена дури и во градската средина. Друг важен фактор, поради кој многу обичаи се одржале, е и потребата за разликување од мнозинското муслиманско население, т.е. од Бошњаците, кои живеат на просторот на Нови Пазар. ${ }^{7}$ Значи, за Србите во овој крај традиционалната култура, покрај верската, претставува важен сегмент за одржување на идентитетот. Обичаите и верувањата поврзани со детето до првата година од животот најмногу се зачувани и поради нивната старина и можноста за истрајување, што е „и разбирливо со оглед на тоа што раѓањето претставува универзален и извонредно значаен, судбински настан. Затоа е лесно да се објасни зошто обредите, со кои една култура му одговара на олку важниот настан и со кои се обидува да го регулира неговиот тек и неговиот поволен резултат, не можат да се менуваат произволно без да се наруши психолошкоопштествената рамнотежа“" (Требјешанин, 1991, 96-97).

Во врска со претходното, со пишувањето на овој труд, целта беше да се обрне внимание „на значајните обичајни и обредни сегменти, оние по кои се препознава српската заедница во новопазарскиот крај, но и на оние врз кои опстојува во оваа средина, којашто со векови е мултиконфесионална и мултикултурална“ (Милорадовић и Аксић, 2019, 401).

И за самиот крај, како потврда на сепак цврстото чување на традицијата, со малку модифицирани елементи, е и следниов цитат на информаторката од

\footnotetext{
${ }^{7}$ Според Пописот на населението од 2011 година, на територијата на Нови Пазар (со селата) живеат $83 \%$ Бошњаци и $16 \%$ Срби.
} 
Нови Пазар, која раскажуваше за повојницата организирана за третото дете што го родила на самиот почеток на 21 век: Веца ми је донела погачу, кајмак, не знам ти шта, не знам ти шта... Кад је дошла први пут, оно баш оно по старински оно (B).

\section{ЛИТЕРАТУРА}

ЂОРЂЕВИЋ, Т. 1941. Деца у веровањима и обичајима нашег народа IX. Зборник здравствених проучавања и испитивања села и народног живота, 46. КУЛИШИЋ, Ш., ПЕТРОВИЋ П. и ПАНТЕЛИЋ Н. 1998. Српски митолошки речник. Београд: Етнографски институт САНУ, бабице и дете.

МИЛОРАДОВИЋ, С. и АКСИЋ Н. 2019. Жито и житни производи у обичајима годишњег и животног циклуса код Срба у новопазарском крају, у: Живот посвећен трагању за етничким идентитетом, 25-42.

РИСТОВИЋ, М. и СТОЈАНОВИЋ Д. (уред.). 2001. Детињство у прошлости 19. и 20. век. Београд: Удружење за друштвену историју.

ТРЕБЈЕШАНИН, Ж. 1991. Представа о детету у српској култури. Београд: Српска књижевна задруга.

Nina Aksich

\section{FOLK CUSTOMS AT BIRTH AND DURING THE FIRST YEAR OF LIFE (THROUGH EXAMPLES OF THE SERBIAN COMMUNITY IN NOVI PAZAR)}

\section{Summary}

The text presents traditional customs related to the acquisition of certain abilities by the child in his first year of life, as well as customs related to the birth and christening of the child, as well as some taboos. Special attention is paid to the customs practiced by members of the Serb community in Novi Pazar. Given that the Serbs are in the minority in this place, it is of particular importance to present ways of preserving the old traditional patterns, which present a form of self-preservation of ethnicity in a majority Muslim environment. With this work we wanted to present the richness of these customs, as well as their modifications in modern times, that arise as a consequence of social changes, and above all, changes in culture and economy in Serbia. 